University of Nebraska - Lincoln

DigitalCommons@University of Nebraska - Lincoln

U.S. National Park Service Publications and

Papers

National Park Service

2007

\title{
The impact of time and field conditions on brown bear (Ursus arctos) faecal DNA amplification
}

\author{
Melanie A. Murphy \\ University of Idaho, melanie.murphy@uwyo.edu \\ Katherine C. Kendall \\ USGS-NRMSC Science Center, kkendall@usgs.gov \\ Andrew P. Robinson \\ University of Idaho, a.robinson@ms.unimelb.edu.au \\ Lisette P. Waits \\ University of Idaho, Iwaits@uidaho.edu
}

Follow this and additional works at: https://digitalcommons.unl.edu/natlpark

Murphy, Melanie A.; Kendall, Katherine C.; Robinson, Andrew P.; and Waits, Lisette P., "The impact of time and field conditions on brown bear (Ursus arctos) faecal DNA amplification" (2007). U.S. National Park Service Publications and Papers. 48.

https://digitalcommons.unl.edu/natlpark/48

This Article is brought to you for free and open access by the National Park Service at DigitalCommons@University of Nebraska - Lincoln. It has been accepted for inclusion in U.S. National Park Service Publications and Papers by an authorized administrator of DigitalCommons@University of Nebraska - Lincoln. 


\title{
The impact of time and field conditions on brown bear (Ursus arctos) faecal DNA amplification
}

\author{
Melanie A. Murphy $\cdot$ Katherine C. Kendall • \\ Andrew Robinson · Lisette P. Waits
}

Received: 27 June 2006/ Accepted: 21 November 2006/Published online: 5 January 2007

(C) Springer Science+Business Media B.V. 2007

\begin{abstract}
To establish longevity of faecal DNA samples under varying summer field conditions, we collected 53 faeces from captive brown bears (Ursus arctos) on a restricted vegetation diet. Each faeces was divided, and one half was placed on a warm, dry field site while the other half was placed on a cool, wet field site on Moscow Mountain, Idaho, USA. Temperature, relative humidity, and dew point data were collected on each site, and faeces were sampled for DNA extraction at $<1,3,6,14,30,45$, and 60 days. Faecal DNA sample viability was assessed by attempting PCR amplification of a mitochondrial DNA (mtDNA) locus $(\sim 150 \mathrm{bp})$ and a nuclear DNA (nDNA) microsatellite locus (180-200 bp). Time in the field, temperature, and dew point impacted mtDNA and nDNA amplification
\end{abstract}

M. A. Murphy · L. P. Waits ( $\square)$

Department of Fish and Wildlife Resources,

University of Idaho, Moscow, ID 83844, USA

e-mail: lwaits@uidaho.edu

Present Address:

M. A. Murphy

School of Biological Sciences, Washington State University,

Pullman, WA 99164, USA

K. C. Kendall

USGS Northern Rocky Mountain Science Center, Glacier

Field Station, Glacier National Park, West Glacier, MT 59936-0128, USA

\author{
A. Robinson \\ Department of Forest Resources, University of Idaho, \\ Moscow, ID 83844, USA \\ Present Address: \\ A. Robinson \\ Department of Mathematics and Statistics, \\ University of Melbourne, Parkville, VIC 3010, Australia
}

success with the greatest drop in success rates occurring between 1 and 3 days. In addition, genotyping errors significantly increased over time at both field sites. Based on these results, we recommend collecting samples at frequent transect intervals and focusing sampling efforts during drier portions of the year when possible.

Keywords DNA preservation - Faecal DNA . Noninvasive genetic sampling - Ursus arctos

\section{Introduction}

To effectively and efficiently apply faecal DNA analysis in large-scale studies, it is important to identify the variables that impact PCR amplification success. Multiple factors in the field and the laboratory may contribute to faecal DNA template quality and quantity. Researchers have demonstrated the importance of laboratory factors including faecal preservation method (Wasser et al. 1997; Murphy et al. 2000; Murphy et al. 2002; Piggott and Taylor 2003), faecal DNA extraction method (Flagstad et al. 1999; Goossens et al. 2000; Frantz et al. 2003; Wehausen et al. 2004), and amplification method (Goossens et al. 2000; Bellemain and Taberlet 2004; Piggott et al. 2004). Important variables in the field include the age of the faecal sample (Fernando et al. 2000; Lucchini et al. 2002; Piggot 2004), weather conditions (Farrell et al. 2000; Lucchini et al. 2002; Piggot 2004), diet (Murphy 2003; Maudet et al. 2004), and potentially intestinal cell slough rate which may differ among species and within species as diets vary by individual or by season (Farrell et al. 2000; Maudet et al 2004). These studies have 
suggested that success rates will be highest when samples are as fresh as possible and climatic conditions are either dry (Farrell et al. 2000; Piggot 2004) or very cold (Lucchini et al. 2002).

To evaluate the impact of time and climatic variables on brown bear ( $U$. arctos) faecal DNA, we designed an experiment that would expose faecal samples to different climatic conditions over a 60-day summer field season. Samples were taken for DNA extraction at seven different time points over this period, and we evaluated three indicators of faecal DNA quality-mitochondrial DNA (mtDNA) amplification rates, nuclear (nDNA) microsatellite amplification rates, and microsatellite genotyping error rates. The results from this study increase our understanding of the relative impact of temperature, moisture and time on faecal DNA degradation and allow us to make recommendations for optimal faecal DNA study design for bears and other species.

\section{Materials and methods}

\section{Sample collection and field design}

Faeces $(n=53)$ were obtained in four collection groups on separate days from a captive brown bear population (4 males, 5 females) at Washington State University (WSU), USA. The four collection groups contained 17, 15, 11, and 10 faeces respectively. The diet of bears was restricted to alfalfa and grass to avoid differences in DNA amplification due to diet (Farrell et al. 2000; Murphy et al. 2003; Nsubuga et al. 2004); each faecal sample was less than $24 \mathrm{~h}$ old when removed from the bear facility. At initial collection, a small portion of the faeces was mixed with a disposable spoon to homogenize intestinal cell distribution. Approximately $6 \mathrm{~g}$ of mixed faeces were collected on silica in an air-tight vial at a 4 (silica): 1 (faeces) ratio to simulate field collection (Wasser et al. 1997; Murphy et al. 2000). The remaining faecal material was placed in a numbered plastic bag maintaining as much of the original structure as possible.

Faeces were immediately transported to Moscow Mountain, $6 \mathrm{~km}$ north of Moscow, Idaho, USA. Faeces were divided into two portions: half of each faeces was placed on a sunny, dry south-facing grassy hillside (site A) and half of each faeces was placed within a relatively cool, wet cedar forest stand (site B) to simulate a range of summer collection conditions. The location and number of each faeces were marked with a plastic garden stake. Temperature, relative humidity, and dew point were collected every three minutes for each site using a Hobo7H sensor. Samples were taken from each faeces at 3, 6, 14, 30, 45, and 60 days post collection between July 15 and September 17, 1998. A small section of the faeces was thoroughly mixed with a plastic spoon before collection when possible to homogenize intestinal cell distributions to avoid bias in collection or effect of possible DNA degradation due to UV exposure. The remaining faeces was left undisturbed so mixing would not interfere with faecal structure and subsequent samples were taken from undisturbed portions of the faeces.

All faecal samples were collected on silica desiccant for transport to the laboratory to be consistent with 1998 bear faeces field collection protocols in Glacier National Park and were dried for $48 \mathrm{~h}$ in a Lyophilizer HKL012 at $-40^{\circ} \mathrm{C}$ and 6-8 atmospheres (Murphy et al. 2000). After freeze-drying, all samples were ground to a fine powder with sterilized equipment and samples were stored at $-80^{\circ} \mathrm{C}$ until DNA extraction (Murphy et al. 2000).

\section{DNA extraction and PCR amplification}

DNA extractions were conducted in a laboratory dedicated to low quantity and quality DNA (Taberlet et al. 1999). Samples were extracted using a QIAmp tissue kit (Qiagen) with a modified protocol then concentrated and purified using a silica pellet method (Geneclean II kit Bio101, Murphy et al. 2000). All DNA extractions, DNA purification, and PCR mixes contained 1-3 negative controls (reagents only) to monitor for any contamination.

Two PCR amplifications were attempted for all samples: 150 bp mtDNA control region locus (Murphy et al. 2000) and 180-200 bp nDNA microsatellite locus (G1A, Paetkau et al. 1995). The mtDNA fragment is generally used to differentiate brown bear (146 bp) and black bear (164 bp) DNA. The nDNA fragment is a microsatellite locus used frequently in brown and black (U. americanus) bear population genetic studies. The relative success of the two loci should also provide information about the quality of the faecal DNA sample as mtDNA is more readily amplified from degraded samples (eg. Murphy et al. 2000). Conditions for PCR are described in detail in Murphy et al. (2000).

For the initial amplification/non-amplification test for both loci, the PCR products were separated on a $1.5 \%$ agarose gel and visualized using ethidium bromide staining and UV radiation. Due to low faecal DNA success rates and high per lane costs of running ABI Prism 377 gels, faecal DNA PCR products are often screened in this manner. However, agarose gels may underestimate success rates compared to the more 
sensitive fluorescent detection systems. When a PCR product was observed in the expected size range, PCR amplification was considered a success. Band strength was not quantified. Lanes were scored blind as positive (product) and negative (no product). All samples that failed in an initial PCR were attempted a second time to account for stochastic non-amplification (Murphy et al. 2000).

\section{Genotyping error rates}

The G1A primer was fluorescently labeled (Tet) and all positive PCR products were genotyped on an ABI Prism 377 DNA sequencer and analyzed using Genescan 2.0 and Genotyper 2.5 software packages. Samples were coded by a randomly applied lab identification number; collection point and site were unknown at the time of analysis. For 27/53 faecal samples, the bear of origin was known because defecation occurred while a single bear was confined to its pen. Therefore, the genotype at G1A could be established by amplification of DNA template from blood or tissue, or by establishing a correct consensus genotype from faecal samples typed multiple times with a multiple tubes approach (Tablerlet et al 1996; Goossens et al. 2000).

All samples with a positive PCR for G1A and a reference genotype were evaluated for genotyping errors. PCR amplifications that deviated from the established genotypes were placed into three categories: (1) allelic dropout (AD), (2) false allele (FA), or (3) multiple alleles (MA) (Murphy et al. 2003). If the established genotype was a heterozygote and only one of the established alleles was present in the PCR amplification, the error was classified as allelic dropout. If the PCR amplification contained alleles not present in the established genotype but fewer than three alleles, the error was classified as a false allele. If the PCR product contained more than two alleles, the error was classified as multiple alleles. Multiple alleles are separated from false alleles for the purposes of this paper because with diploid organisms multiple alleles are an unambiguous error while false alleles can be misinterpreted as true alleles and degrade data quality (Goossens et al 2000).

\section{Data analysis}

We calculated minimum, maximum, average, and range for each weather variable (temperature, relative humidity, dew point) in each sampling group $(n=4)$ by site (open versus closed) for each time point as potential explanatory variables. Because amplification success rates declined sharply after $<1$ day, an additional dummy variable was included to test if the $<1$ day time point was significantly different from the remaining time points. The response variable for each model is: (1) the proportion of successful mtDNA PCR amplifications, (2) the proportion of successful nDNA PCR amplifications, and (3) the proportion of genotyping errors for each group at each site over time respectively. Because these response variables are the proportion of success, they follow a binary distribution. Therefore, data were analyzed using Generalized Estimating Equations (GEE) in SAS 7.0 (SAS Institute Inc. 1999) which are appropriate for repeated measures for distributions from the exponential family.

We set the following model conditions: binomial distribution (logit), response variable evaluated by group for each site (class group (site)), repeated measures with autocorrelation (time series component), and analysis by marginal tests, via the so-called Type 3 analysis. Type 3 analysis is analogous to a Type III sums of squares in Generalized Linear Models, and the results do not depend on the order in which model terms are specified (SAS Institute Inc. 1999). The time, weather variables (minimum, maximum, average and range for dew point, relative humidity, and temperature) and all two-term interactions were tested for significance and contribution to model fit $(\alpha=0.05)$. If the $P$-value of the parameter was greater than $\alpha=0.05$, the parameter was removed from the model. Overall model fit was evaluated by log likelihood values and scaled deviance (SAS Institute Inc. 1999).

\section{Results}

Weather data and field collections

The weather station at Moscow, Idaho received $1.49 \mathrm{~cm}$ of rainfall during the study period (July 15-September 17, 1998). At site A, temperature readings ranged from $4.20^{\circ} \mathrm{C}-51.79^{\circ} \mathrm{C}$, with an average daily temperature of $19.75^{\circ} \mathrm{C}$, and daily fluctuations averaged $38.83^{\circ} \mathrm{C}$. Relative humidity ranged from $2.50 \%-104.20 \%$, with an average relative humidity of $55.65 \%$, and daily fluctuations averaged $64.31 \%$. Dew point ranged from $1.33^{\circ} \mathrm{C}-32.81^{\circ} \mathrm{C}$ with an average dew point of $9.92^{\circ} \mathrm{C}$. The outer layer of the faeces desiccated in 1-3 days, while the inner portion of the faeces was completely desiccated in 6-9 days.

On site $\mathrm{B}$, temperature readings ranged $8.47^{\circ} \mathrm{C}-$ $43.12^{\circ} \mathrm{C}$ with an average daily temperature of $19.54^{\circ} \mathrm{C}$ and daily fluctuation averaged $21.21{ }^{\circ} \mathrm{C}$. Relative humidity ranged from $13.97 \%-105.76 \%$ with an 
average relative humidity of $58.89 \%$ and daily fluctuation averaged $32.98 \%$. Dew point ranged from $3.49^{\circ} \mathrm{C}-35.97^{\circ} \mathrm{C}$ with an average dew point of $12.6^{\circ} \mathrm{C}$. After faeces were placed on site $\mathrm{B}$, they remained moist throughout the faecal matter and fungal spores covered the surface on $86.79 \%(46 / 53)$ of the faeces within three days. By 14 days, all spores had subsided but faecal matter remained moist in the interior, and most samples did not completely desiccate.

\section{Faecal DNA PCR amplification success rates}

Brown bear faecal DNA successfully amplified in $53.17 \%(789 / 1484)$ of PCR amplifications. PCR amplification was unsuccessful in the first attempt but successful in the second attempt for $1.48 \%(11 / 742)$ at the mtDNA DNA locus and $8.22 \%(61 / 742)$ for the nDNA locus. Overall, faecal DNA PCR amplification success was higher for mtDNA $(69 \%)$ than nDNA (37\%). For mtDNA, PCR amplification success before treatment ( $<1$ day) was $84.91 \%$. From the site A, mtDNA PCR amplification success rates ranged from $62.26 \%$ (60 days) $-79.25 \%$ (45 days) (Fig. 1). From the site B, mtDNA PCR amplification success rates ranged from $54.72 \%$ (60 days) - 69.81\% (3 days; Fig. 1). The selected model for mtDNA PCR amplification success was $(\Phi / d f=1.2540)$ :

$$
\begin{aligned}
& \log \left(\frac{\mathrm{P}(\mathrm{mtDNAsuccess})}{1-\mathrm{P}(\mathrm{m} t \mathrm{DNAsuccess})}\right) \\
&= 1.0992-0.2794 \text { Time }+ \text { 0.0123Time*AveDew } \\
&+ \text { 0.0034Time*TempRange }
\end{aligned}
$$

All model terms were statistically significant $P \leq 0.05$ (Table 1).

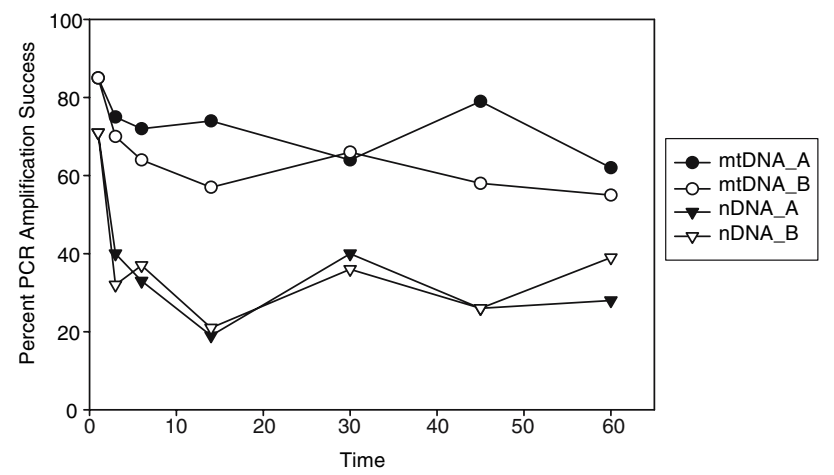

Fig. 1 Temporal analysis of PCR success rates for the amplification of mtDNA and nDNA loci from 53 brown bear faecal samples. Success rates are displayed as percent success across time in days
For nDNA, PCR amplification success before treatment (<1 day) was $71.70 \% \quad(38 / 53)$. Nuclear DNA amplification success from site A ranged from $18.87 \%$ (14 days) - 39.62\% (30 and 60 days; Fig. 1). Nuclear DNA amplification success from site B ranged from $20.74 \%$ (60 days) - 39.62\% (3 days) Fig. 1. The selected model for nDNA PCR amplification success was $(\Phi / d f=1.1899)$ :

$$
\begin{aligned}
\log ( & \left.\frac{\mathrm{P}(\mathrm{nDNAsuccess})}{1-\mathrm{P}(\mathrm{nDNAsuccess})}\right) \\
= & -0.6008+2.5963<1 \text { day }-0.2654 \text { Time } \\
& +0.0130 \text { Time*AveDew } \\
& +0.0030 \text { Time*TempRange }
\end{aligned}
$$

All retained model terms were statistically significant at $P \leq 0.05$ (Table 1 ).

\section{Error rates}

For faecal samples from known bears, 62.88\% (61/97) of positive PCR products matched the genotype established from blood, tissue, or CCG (Table 2). Of the positive PCR products that did not match established genotypes, $5.15 \%(5 / 97)$ were classified as AD, 9.28\% (9/97) were classified as FA, and 24.74\% (24/97) were classified as MA (Table 2). Combining all errors types, $18.75 \%(3 / 16)$ of positive PCR products from known bears had errors at initial sampling ( $<1$ day). From site A, observed error rates ranged from $14.29 \%$ (1/7; 6 days) $-57.14 \%$ (4/7; 60 days; Table 2$)$. From site $\mathrm{B}$, error rates ranged from $25.00 \%$ (2/8; 3 days)$66.67 \%$ (6/9; 60 days; Table 2). The selected model for probability of a genotyping error given a positive PCR product was $(\Phi=25.2067, d f=36, \Phi / d f=0.7002)$ :

$\log \left(\frac{\mathrm{P}(\text { error } \mid \text { positivePCR })}{1-\mathrm{P}(\text { error } \mid \text { positivePCR })}\right)=-1.2655+0.0310$ time

Time was statistically significant in the model $\left(\chi_{1}^{2}=5.33, P=0.0210\right)$ and no other tested terms were statistically significant or increased model fit.

\section{Discussion}

Our results indicate that time in the field, dew point and temperature significantly impact DNA amplification success rates. Time was a critical variable in all three models and had the strongest effect. There was also a difference in success rates between samples placed in the dry, warm site (A) and the cooler, more 
Table 1 Model parameters for probability of mtDNA and nDNA amplification success model giving parameter estimate, $\chi^{2}$ value, and $P$-value $(d f=1$ for all parameter estimates)

\begin{tabular}{|c|c|c|c|c|c|c|}
\hline & \multicolumn{3}{|l|}{ mtDNA } & \multicolumn{3}{|l|}{ nDNA } \\
\hline & Parameter estimate & $\chi^{2}$ & $P$-value & Parameter estimate & $\chi^{2}$ & $P$-value \\
\hline Intercept & 1.0992 & 60.64 & $<0.0001$ & -0.6008 & 17.13 & $<0.0001$ \\
\hline Time & -0.2794 & 7.95 & 0.0048 & -0.2654 & 6.31 & $<0.0001$ \\
\hline Time*AveDew & 0.0123 & 5.67 & 0.0173 & 0.0130 & 5.43 & 0.0120 \\
\hline Time*TempRange & 0.0034 & 9.50 & 0.0021 & 0.0030 & 6.79 & 0.0198 \\
\hline$<1$ day & NA & NA & NA & 2.5963 & 70.60 & 0.0092 \\
\hline
\end{tabular}

Table 2 Correct genotypes (CG) are the number of correct genotypes out of the total number of genotypes for samples where the individual was known.

\begin{tabular}{|c|c|c|c|c|c|c|c|c|}
\hline \multirow[t]{2}{*}{ Days } & \multicolumn{4}{|l|}{ Open } & \multicolumn{4}{|l|}{ Closed } \\
\hline & $\overline{\mathrm{CG}}$ & $\mathrm{AD}$ & FA & MA & $\overline{\mathrm{CG}}$ & $\mathrm{AD}$ & FA & MA \\
\hline$<1$ & $81(13 / 16)$ & $6(1 / 16)$ & $6(1 / 16)$ & $6(1 / 16)$ & $81(13 / 16)$ & $6(1 / 16)$ & $6(1 / 16)$ & $6(1 / 16)$ \\
\hline 3 & $67(4 / 6)$ & $0(0 / 6)$ & $0(0 / 6)$ & $33(2 / 6)$ & $75(6 / 8)$ & $13(1 / 8)$ & $0(0 / 8)$ & $13(1 / 8)$ \\
\hline 6 & $86(6 / 7)$ & $0(0 / 7)$ & $0(0 / 7)$ & $14(1 / 7)$ & $71(5 / 7)$ & $0(0 / 7)$ & $14(1 / 7)$ & $14(1 / 7)$ \\
\hline 14 & $67(4 / 6)$ & $0(0 / 6)$ & $17(1 / 6)$ & $11(1 / 6)$ & $50(2 / 4)$ & $0(0 / 4)$ & $0(0 / 4)$ & $50(2 / 4)$ \\
\hline 30 & $56(5 / 9)$ & $11(1 / 9)$ & $11(1 / 9)$ & $22(2 / 9)$ & $50(3 / 6)$ & $0(0 / 6)$ & $17(1 / 6)$ & $33(2 / 6)$ \\
\hline 45 & $57(4 / 7)$ & $0(0 / 7)$ & $14(1 / 7)$ & $29(2 / 7)$ & $43(3 / 7)$ & $0(0 / 7)$ & $14(1 / 7)$ & $43(3 / 7)$ \\
\hline 60 & $43(3 / 7)$ & $14(1 / 7)$ & $14(1 / 7)$ & $29(2 / 7)$ & $33(3 / 9)$ & $11(1 / 9)$ & $11(1 / 9)$ & $44(4 / 9)$ \\
\hline Ave & $67(39 / 58)$ & $5(3 / 58)$ & $9(5 / 58)$ & $19(11 / 58)$ & $61(35 / 57)$ & $5(3 / 57)$ & $9(5 / 57)$ & $25(14 / 57)$ \\
\hline
\end{tabular}

PCR errors were classified as allelic dropout (AD), false alleles (FA) and multiple alleles (MA, see methods). Values are as follows: percent of genotypes in class (total genotypes in class/number total genotypes). All error types were combined for model building in order to have sufficient sample size

moist site (B). In spite of these effects, relatively high mtDNA success rates (65-85\%) were observed up to 45 days post defecation in the tested range of weather conditions (Fig. 1). Thus, researchers who want to use faecal DNA for species identification or mtDNA phylogeographic studies can expect moderate to high success rates from standard field surveys in a variety of climatic conditions.

In contrast, faecal nDNA PCR amplification success declined from $71 \%$ after initial sampling to $19-40 \%$ (Fig. 1). Time, temperature, and dew point all impact nDNA amplification success (Table 1), and microsatellite genotyping error rates significantly increased over time (Table 2). This highlights the importance of working with fresh specimens and using comprehensive error checking protocols (Taberlet et al. 1996; Miller et al. 2002). There is a possibility that weather effects were statistically confounded with other unmeasured environmental effects at each site, but we are confident that our conclusions and recommendations are valid.

\section{Comparison to other studies}

Four other studies have investigated the impact of time and weather conditions on faecal DNA PCR amplification success (Farrell et al. 2000; Fernando et al. 2000; Lucchini et al. 2002; Piggott 2004). Fernando et al. (2000) studied the impact of time on faecal mtDNA amplification success in Asian elephants (Elephus maximus) and found mtDNA could be successfully sequenced from samples up 8 days old but they were unable to amplify samples older than 8 days. Farrell et al. (2000) collected faecal samples for mtDNA analysis from four carnivore species and compared amplification success rates between the wet and dry seasons. In the dry season, $66 \%$ (18/27) of the samples amplified successfully while PCR amplification success for samples from the wet season was only $28 \%(2 / 7)$. Similarly low success rates have been observed with faeces collected from aquatic species (Reed et al. 1997; Dallas et al. 2000). In addition, collection of samples from snow-covered ground appears to increase success rates as samples remain frozen (Lucchini et al. 2002). In a comparison of faecal DNA amplification success across six months and two seasons for the brush-tailed rock-wallaby (Petrogale penicilata) and the red fox (Vulpes vulpes), Piggot (2004) detected a decrease in nDNA amplification success and an increase in genotyping errors over time and in winter as rainfall increased. Our results are consistent with these findings.

Implications for future studies

Based on this study, faecal DNA sampling should attempt to use only the freshest samples collected from the driest field conditions possible. In addition, our low 
nDNA PCR amplification success rates after only three days in the field suggest that frequent transects are needed to obtain high quality faecal DNA samples for brown bears and potentially other species when working in similar climates. Researchers will need to balance the cost of running frequent transects with the benefits of increased success rates. When success rates decrease and error rates increase, laboratory costs rise and may offset some of the increased field expense.

In addition, other methods can be applied to increase overall success rates. Improvements in faecal sample preservation (Murphy et al. 2002; Piggott and Taylor 2003) and PCR amplification (Bellemain and Taberlet 2004; Piggott et al. 2004) may increase overall amplification success. Researchers working with ungulates have shown that collection of faecal material from the outer portions of the faeces can improve amplification success rates when compared to methods that homogenize faecal material (Flagstad et al 1999). Recent work in Scandinavia has demonstrated that under some environmental conditions, nDNA success rates for hunter-collected brown bear faecal samples can be increased to $>70 \%$ (Bellemain and Taberlet 2004; Bellemain et al. 2005). Interestingly, much lower success rates $(35-50 \%)$ have been observed when using the same protocols for brown bear faeces collected in France and Italy (Bellemain, per com; Waits unpublished) potentially due to differences in diet and/or climate.

Acknowledgments We would like to thank the following people for laboratory assistance and protocol optimization: Christine Cegelski, Christine Clarke, Carol Perugini, Jeffrey Stetz, and Dr. Samuel Wasser. For use of laboratories and field sites we thank Dr. Steve Brunsfeld, Dr. Rodney Mead, and Dr. Ed Krumpe. We especially thank Dr. Charles Robbins for use of the captive brown bear facility at Washington State University. We also thank Jeffrey Evans for helpful comments on drafts of this paper. Finally, we thank two anonymous reviewers, whose generous comments greatly improved this manuscript.

\section{References}

Bellemain E, Swenson JE, Tallmon D, Brunberg S et al (2005) Estimating population size from hunter-collected feces: four methods for brown bears. Conserv Biol 19:150-161

Bellemain E, Taberlet P (2004) Improved non-invasive genotyping method: application to brown bear (Ursus arctos) faeces. Mol Ecol Notes 4:519-522

Dallas JF, Carss DN, Marshall F, Koepfli K-P et al (2000) Sex identification of the Eurasian otter Lutra lutra by PCR typing of spraints. Conserv Gen 1:181-183

Farrell LE, Roman J, Sunquist ME (2000) Dietary separation of sympatric carnivores identified by molecular analysis of scats. Mol Ecol 9:1583-1590

Fernando PJ, Pfrender ME, Encalada SE, Lande R (2000) Mitochondrial DNA variation, phylogeography and population structure of the Asian elephant. Heredity 84: 362-372
Flagstad Ø, Roed K, Stacy JE, Jakobsen KS (1999) Reliable noninvasive genotyping based on excremental PCR of nuclear DNA purified with a magnetic bead protocol. Mol Ecol 8:879-883

Frantz AC, Pope LC, Carpenter PJ, Roper TJ et al (2003) Reliable microsatellite genotyping of the Eurasian badger (Meles meles) using faecal DNA. Mol Ecol 12:1649-1661

Goossens B, Chikhi L, Utami SS, Ruiter Jd et al (2000) A multisamples, multi-extracts approach for microsatellite analysis of faecal samples in an arboreal ape. Conserv Gen 1:157-162

Lucchini V, Fabbri E, Marucco F, Ricci S et al (2002) Noninvasive molecular tracking of colonizing wolf (Canis lupus) packs in the western Italian Alps. Mol Ecol 11:857-868

Maudet C, Luikart G, Dubray D, Von Hardenberg A, Taberlet P (2004) Low genotyping error rates in ungulate feces sampled in winter. Mol Ecol Notes 4:772-775

Miller C, Joyce P, Waits L (2002) Assessing allelic dropout and genotype reliability using maximum likelihood. Genetics 160:357-366

Murphy MA, Waits LP, Kendall KC (2000) Quantitative evaluation of fecal drying methods for brown bear DNA analysis. Wildl Soc Bull 28:951-957

Murphy MA, Waits LP, Kendall KC (2003) The influence of diet on faecal DNA amplification and sex identification in brown bears (Ursus arctos). Mol Ecol 12:2261-2265

Murphy MA, Waits LP, Kendall KC, Wasser SK et al (2002) An evaluation of long-term preservation methods for brown bear (Ursus arctos) faecal DNA samples. Conserv Gen 3:435-440

Nsubuga AM, Robbins MM, Roeder AD, Morin PA et al (2004) Factors affecting the amount of genomic DNA extracted form ape faeces and the identification of an improved sample storage method. Mol Ecol 13:2089-2094

Paetkau D, Calvert A, Stirling J, Strobeck C (1995) Microsatellite analysis of population structure in Canadian polar bears. Mol Ecol 4:347-354

Piggott MP (2004) Effect of sample age and season of collection on the reliability of microsatellite genotyping of faecal DNA. Wildl Res 31:485-493

Piggott MP, Bellemain E, Taberlet P, Taylor AC (2004) A multiplex pre-amplification method that significantly improves microsatellite amplification and error rates for faecal DNA in limiting conditions. Conserv Gen 5:417-420

Piggott MP, Taylor AC (2003) Extensive evaluation of faecal preservation and DNA extraction methods in Australian native and introduced species. Aust J Zool 51:341-355

Reed Z, Tollit DJ, Thompson PM, Amos W (1997) Molecular scatology: the use of molecular genetic analysis to assign species, sex and individual identity to seal faeces. Mol Ecol 6:225-234

SAS Institute Inc. (1999) SAS/STAT User's Guide, Version 8, SAS Institute Inc, Cary, NC

Taberlet P, Griffin S, Goossens B, Questiau S, et al (1996) Reliable genotyping of samples with very low DNA quantities using PCR. Nucleic Acids Res 24:3189-3194

Taberlet P, Waits LP, Luikart G (1999) Noninvasive genetic sampling: look before you leap. Trends Ecol Evol 14:323-327

Wasser SK, Houston CS, Koehiler GM, Cadd GG et al (1997) Techniques for applications of faecal DNA methods to field studies of Ursids. Mol Ecol 6:1091-1097

Wehausen JD, Ramey RR II, Epps CW (2004) Experiments in DNA extraction and PCR amplification from Bighorn Sheep feces: the importance of DNA extraction method. J Heredity 95:503-509 